\title{
SYP Gene
}

National Cancer Institute

\section{Source}

National Cancer Institute. SYP Gene. NCI Thesaurus. Code C101144.

This gene is involved in vesicle targeting and synaptic plasticity. 